\title{
Perancangan Strategi Pemasaran dengan Menggunakan Metode Swot di CV. Sekar Sari Roti Pekanbaru
}

\author{
Misra Hartati ${ }^{1}$, Rahmat Rohim ${ }^{1}$ \\ ${ }^{1,2}$ Jurusan Teknik Industri, Fakultas Sains dan Teknologi, UIN Sultan Syarif Kasim Riau \\ Jl. HR. Soebrantas No. 155 Simpang Baru, Panam, Pekanbaru, 28293 \\ Email: misrahartati@uin-suska.ac.id, rahmat.rohim@gmail.com
}

\begin{abstract}
Abstrak
CV. Sekar Sari Roti merupakan industri pembuatan roti seperti roti manis, tawar, selai dan lain-lain. CV. Sekar Sari Roti mempunyai target produksi sebesar 9000 unit/bulan. Dengan tingginya target yang ingin di capai, sehingga perusahaan harus mempunyai strategi pemasaran. Ketatnya persaingan industri yang berada dikawasan Pekanbaru menyebabkan berkurangnya pangsa pasar dan pemasaran produk tidak merata Manfaat yang diharapkan dari penelitian ini adalah Perusahaan dapat mengetahui posisi strategi organisasinya saat ini yang dilihat dari faktor ekternal dan faktor internal serta mengetahui posisi strategi perusahaan. Penelitian ini menggunakan metode SWOT. Melalui penerapan metode SWOT ini, CV. Sekar Sari Roti dapat merancang strategi pemasaran dan posisi strategi perusahaan dengan tahapan penilaian faktor Internal dan eksternal serta diagram SWOT dan analisa diagram fishbone. Berdasarkan metode SWOT menunjukkan posisi strategi di CV. Sekar Sari Roti berada pada kuadran II Stability yaitu memanfaatkan peluang yang ada dengan cara meminimalkan kelemahan yang ada.
\end{abstract}

Kata Kunci : Fishbone, Pemasaran, SWOT.

\section{Latar Belakang}

Perkembangan bisnis di Indonesia semakin lama semakin menonjol akan kompleksitas, persaingan, perubahan, dan ketidakpastian. Keadaan ini menimbulkan persaingan yang tajam antara perusahaan, sehingga memaksa perusahaan untuk lebih memperhatikan lingkungan yang dapat mempengaruhi perusahaan, agar perusahaan mengetahui strategi pemasaran seperti apa dan bagaimana yang harus diterapkan dalam perusahaan (Rangkuti, 2011).

CV. Sekar Sari Roti merupakan industri pembuatan roti seperti roti manis, tawar, selai dan lain-lain. CV. Sekar Sari Roti mempunyai target produksi sebesar 9000 unit/bulan. Dengan tingginya target yang ingin di capai, sehingga perusahaan harus mempunyai strategi pemasaran. Perusahaan dalam menjalankan usahanya selalu mengutamakan citra perusahaan yang baik serta berusaha menjadi perusahaan yang terkemuka dibidangnya. Ketatnya persaingan industri yang berada dikawasan Pekanbaru menyebabkan berkurangnya pangsa pasar dan pemasaran produk tidak merata sehingga perusahaan harus dapat menyusun strategi-strategi pemasaran sebaik mungkin dengan cara memanfaatkan kekuatan dan peluang yang ada disamping itu perusahaan harus dapat mengantisipasi gerakan pesaing dan ancaman. pesaing dari CV. Sekar Sari Roti yaitu Salsa bakery dan bunda bakery. hal ini menyebabkan berkurangnya pangsa pasar dan pemasaran produk yg dialami oleh pihak CV. Sekar Sari Roti. Sehingga menuntut pihak perusahaan untuk menentukan serta merencanakan strategi pemasaran yang baik bagi perusahaan. Penetapan strategi pemasaran akan mempengaruhi minat masyarakat terhadap produk perusahaan. Adapun data penjualan pada tahun 2012 sampai tahun 2014 di CV. Sekar Sari Roti adalah sebagai berikut :

Tabel 1. Data Penjualan CV. Sekar Sari Roti Tahun 2012-2014

\begin{tabular}{|c|c|c|c|c|c|c|}
\hline Bulan & Tahun 2012 & Persentase & $T$ ahun 2013 & Persentase & Tahun 2014 & Persentase \\
\hline Januari & $32,725,000$ & $9,15 \%$ & $37,631,000$ & $10.25 \%$ & $34,243,000$ & $9,64 \%$ \\
\hline Februari & $30,102,000$ & $8,42 \%$ & $35,241,000$ & $9,60 \%$ & $36,222,000$ & $10,20 \%$ \\
\hline Maret & $31,321,000$ & $8,76 \%$ & $34,731,000$ & $9,46 \%$ & $29,651,000$ & $8,35 \%$ \\
\hline April & $33,921,000$ & $9,48 \%$ & $37,737,000$ & $10,28 \%$ & $33,843,000$ & $9,53 \%$ \\
\hline Mei & $35,111,000$ & $9,82 \%$ & $35,182,000$ & $9,58 \%$ & $37,239,000$ & $10,49 \%$ \\
\hline Juni & $30,432,000$ & $8,51 \%$ & $29,616,000$ & $8,06 \%$ & $32,279,000$ & $9,09 \%$ \\
\hline Juli & $32,404,000$ & $9,60 \%$ & $20,392,000$ & $5,55 \%$ & $20,244,000$ & $5,70 \%$ \\
\hline Agustus & $20,344,000$ & $5,69 \%$ & $22,776,000$ & $6,20 \%$ & $21,052,000$ & $5,93 \%$ \\
\hline September & $21,350,000$ & $5,97 \%$ & $25,414,000$ & $6,92 \%$ & $27,768,000$ & $7,82 \%$ \\
\hline Oltober & $25,992,000$ & $7,27 \%$ & $23,325,000$ & $6,35 \%$ & $24,479,000$ & $6,89 \%$ \\
\hline November & $30,900,000$ & $8,64 \%$ & $31,205,000$ & $8,50 \%$ & $28,707,000$ & $8,08 \%$ \\
\hline Desember & $32,890,000$ & $9,20 \%$ & $33,773,000$ & $9,20 \%$ & $29,246,000$ & $8,23 \%$ \\
\hline & $357,492,000$ & & $367,023,000$ & & $354,973,000$ & \\
\hline
\end{tabular}

Sumber : Data Penjualan CV. Sekar Sari Roti 20122014 


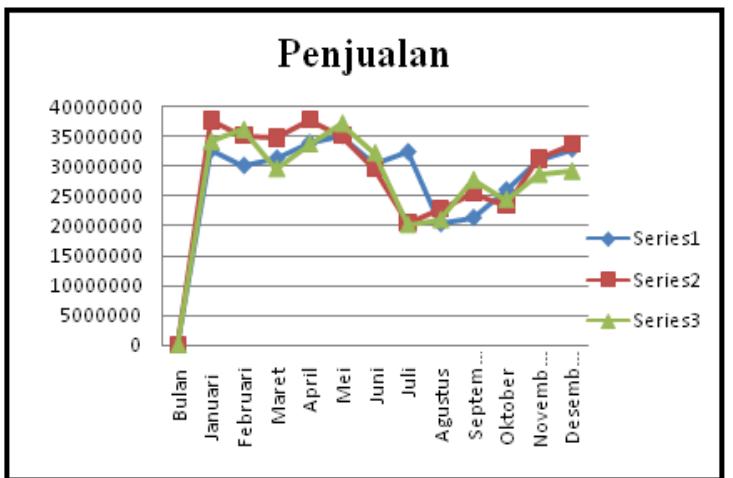

Gambar 1. Grafik Penjualan Tahun 2010-2014

Dari grafik penjualan roti diatas dapat dilihat mengalami penurunan penjualan dari bulan januari sampai desember. Adapun sebab-sebab terjadinya penurunan yaitu, kurangnya strategi pemasaran sehingga tidak mampu bersaing dengan produk sejenisnya, melemahnya nilai tukar rupiah sehingga berdampak pada kemampuan daya beli masyarakat, kenaikan harga bahan bakar minyak sehingga harga jual produk ikut mengalami kenaikan dan minat beli masyarakat menurun, banyaknya pesaing dengan produk sejenis.

\section{Rumusan Masalah}

Dari latar belakang dapat dirumuskan masalah dalam penelitian ini yaitu:

1. Bagaimana mengetahui kekuatan, kelemahan, peluang dan ancaman, pada CV. Sekar Sari Roti dalam penjualan produk dengan menggunakan analisis SWOT?

2. Bagaimana mengetahui posisi strategi perusahaan CV. Sekar Sari Roti dalam penjualan produk dengan membandingkan empat alternatif dalam satu diagram yang dilihat dari faktor eksternal dan faktor internal pada saat ini?

3. Bagaimana merancang strategi baru untuk perusahaan CV. Sekar Sari Roti?

\section{Tujuan Penelitian} berikut:

Tujuan dari penelitian ini adalah sebagai

1. Untuk mengetahui kekuatan, kelemahan, peluang dan ancaman pada CV. Sekar Sari Roti dalam penjualan produk dengan menggunakan analisis SWOT.

2. Untuk mengetahui posisi strategi perusahaan CV. Sekar Sari Roti dengan membandingkan empat alternatif dalam satu diagram yang dilihat dari faktor Eksternal dan faktor Internal pada saat ini.

3. Untuk merancang strategi baru untuk perusahaan CV. Sekar Sari Roti.

\section{Batasan Masalah}

Agar permasalahan tidak terlalu luas ruang lingkupnya, maka penulis membatasi masalah yang diteliti sebagai berikut :

1. Penelitian hanya dilakukan di wilayah Pandau Raya - Pekanbaru.

2. Dalam penelitian ini penulis tidak membahas tentang biaya dan keuangan perusahaan untuk menghindari kerahasiaan perusahaan.

\section{Tinjauan Pustaka}

\section{Pengertian Pemasaran}

Salah satu defenisi pemasaran adalah memenuhi kebutuhan secara menguntungkan. Secara luas pemasaran adalah proses sosial dan manejerial dimana pribadi atau organisasi memperoleh apa yang mereka butuhkan dan diinginkan melalui penciptaan dan pertukaran nilai dengan yang lain.

Ada banyak defenisi tentang pemasaran. Pada dasarnya strategi pemasaran memberikan arah dalam kaitannya dengan variabel-variabel seperti segmentasi pasar, identifikasi pasar sasaran, positioning elemen bauran pemasaran, dan biaya bauran pemasaran. Dalam pranan strateginya, pemasaran mencakup setiap usaha untuk mencapai kesesuaian antara perusahaan dengan lingkungannya dalam rangka mencari pemecahan atas masalah penentuan dua pertimbangan pokok. Pertama, bisnis apa yang digeluti. Kedua, bagaimana bisnis yang telah dipilih tersebut dapat dijalankan dengan sukses dalam lingkungan yang kompetitif atas dasar perspektif produk, harga, promosi, dan distribusi (bauran pemasaran) untuk melayani pasar sasaran.

Dalam aplikasi manajemen strategi pemasaran ada satu sisi yang perlu diperhatikan yaitu budaya. Bahwa perusahaan-perusahaan besar ternyata telah menjadikan budya sebagai catatan penting dalam penciptaan dan pemasaran produk mereka. Dalam persoalan warna saja itu telah menjadi salah satu faktor yang mempengaruhi keputusan perilaku pembelian konsumen. Untuk mendukung kesuksesan strategi pemasaran yang diinginkan maka perlu dirancang suatu rencana pemasaran (marketing plan) . rencana pemasaran adalah instrumen sentral untuk mengarahkan dan mengordinasikan usaha pemasaran, rencana pemasaran beroperasi pada dua level, yaitu stratejik dan taktis. Rencana pemasaran stratejik membentangkan pasar sasaran dan proporsi nilai yang akan ditawarkan, berdaasarkan suatu analisis peluang pasar terbaik. Rencana pemasaran taktis menspesipikasikan taktik pasar, termasuk fitur produk, promosi, perdagangan harga, saluran penjualan, dan layanan (Fahmi, 2013). 


\section{Definsi Manajemen Strategi}

Manajemen strategi adalah suatu rencana yang disusun dan dikelola dengan memperhitungkan berbagai sisi dengan tujuan agar pengaruh rencana tersebut bisa memberikan dampak positif bagi organisasi secara jangka panjang. Salah satu fokus kajian dalam manajemen strategi ingin memberikan dampak penerapan konsep strategi perusahaan secara jangka panjang termasuk dari segi profit yang stabil. Profit yang stabil dipengaruhi oleh stabilitas penjualan yang terus mengalami pertumbuhan (Fahmi, 2013).

Secara umum ruang lingkup kajian manajemen strategi sangat luas baik dari segi internal dan eksternal. Namun secara umum ruang lingkup kajian manajemen strategi bergerak atas dasar pemahaman dibawah ini (Fahmi, 2013) :

a. Mengkaji dan menganalisis dampak penerapan manajemen strategi kepada internal perusahaan khususnya pada perbaikan bersifat berkelanjutan

b. Menempatkan konstruksi manajemen strategi sebagai dasar pondasi perusahaan dan memutuskan setiap keputusan, khususnya keputusan yang berhubungan dengan profit dan ekspansi perusahaan. Artinya fokus kerja dalam pencapaian kedua sisi tersebut mengacu kepada konstruksi manajemen strategi.

c. Menjadikan ilmu manajemen strategi sebagai base thinking dalam membangun berbagai rencana termasuk rencana produksi, pemasaran, personalia, dan keuangan.

\section{Cara Membuat Program-Program Pemasaran}

Ada beberapa hal yang harus diperhatikan untuk membuat program-program dalam pemasaran:

1. Produk

Pemberian nama produk harus mudah diingat dan menggambarkan fungsi/ manfaat untuk memenuhi kebutuhan pelanggan terhadap pelayanan produk tersebut. Kemasan, dalam membuat konsep kemasan untuk bungkus produk maupun tempat penyimpanan produk yang akan diberikan agar memenuhi fungsi sebagai pelindung, menyatakan suatu mutu tertentu dan dijaga agar sesuai dengan selera konsumen

2. Harga
a. Faktor penentuan harga produk ( eksternal dan internal )
b. Berdasarkan biaya plus dengan membuat mark up tertentu diatas biaya rill total pembelian produk tersebut
c. Berdasarkan analisis

d. Berdasarkan persepsi konsumen melalui survey ditanyakan langsung kepada konsumen

e. Berdasarkan persaingan, terutama dengan harga jual produk kompotitor lain.

3. Promosi

a. Iklan, menetapkan sasaran terhaap pelanggan internal

b. Menetapkan anggaran periklanan berdasarkan kemampuan perusahaan, persentase dari hasil penjualan, persaingan, maupun menurut sasaran maupun program

c. Menciptakan pesan iklan

d. Memilih media periklanan, jangkauan, frekuensi, dan dampak dari media utama yang dipilih

e. Memasang spanduk dan brosur lewat forum komunitas sosial

f. Mengevaluasi program periklanan, pengaruh komuniksi iklan

4. Promosi Penjualan

a. Memberikan diskon khusus dalam priode tertentu untuk produk tertentu

b. Penetapan promosi harus mempertimbangkan besarnya insentif yang akan diberikan, syarat konsumen yang diberi insentif secara metode, waktu, dan anggaran promosi penjualan

5. Publisitas

a. Public relations oleh seluruh karyawan, siaran pers, komunikasi antar perusahaan, lobi dengan para profesional produk dan penyuluhan lewat forum komunitas sosial

b. Mengevaluasi efektivitas dengan menghitung banyaknya paparan dalam media, mengukur tingkat perubahan sikap atas publisitas, dan mengukur dampak hasil penjualan dan frofit

6. Distribusi
a. Pembuatan saluran melalui satelit dibeberapa lokasi yang memiliki permintaan dan sirkulasi yang tinggi terhadap produk
b. Penentuan lokasi perusahaan aksesibilitas dan terlihat dari luar)
c. Kriteria evaluasi masing-masing alternatif saluran, biaya, profit, mudah dikendalikan, tingkat persaingan, prilaku konsumen
d. Keterjangkauan biaya, tidak membutuhkan waktu lama dalam proses perawatan produk 


\section{SWOT (Strength, Weakness, Opportinities and Threat)}

SWOT adalah singkatan dari strenghts (Kekutan), weaknesses (Kelemahan), Opportunities (Peluang), dan threats (Ancaman), dimana SWOT ini dijadikan suatu model dalam menganalisis suatu organisasi yang berorientasi profit dan nonprofit dengan tujuan utama untuk mengetahui keadaan organisasi tersebut secara lebih komprehensif

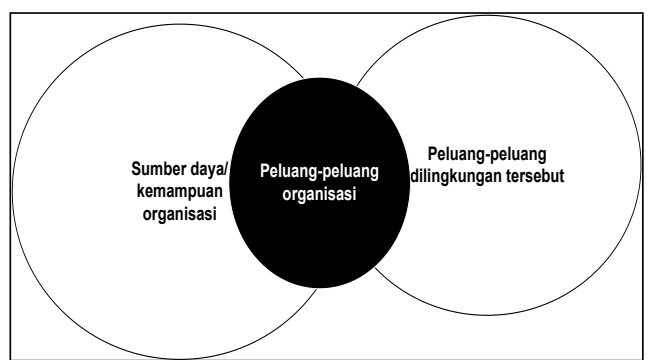

(Fahmi, 2013).

Gambar 2. Peluang-Peluang Organisasi

Ada hal yang harus diingat bahwa analisis SWOT tidak hanya menarik untuk dikaji oleh para manajer atau para top management perusahaan, namun menjadi lebih menarik juga jika dikaji secara pribadi. Terutama untuk melihat potensi dari seseorang serta prospek yang akan diraih dalam pekerjaannya dimasa depan. Ini sebagaimana dikatakan oleh Stephen P. Robbins dan Mary Coulter bahwa, sebuah analisis SWOT dapat merupakan alat yang bermanfaat untuk memeriksa keterampilan, kemampuan, pilihan karir, dan peluang-peluang karir anda sendiri.

\section{Analisa SWOT dan Manajemen Pengambilan Keputusan}

Dalam usaha mendukung manajemen pengambilan keputusan maka analisis SWOT memiliki peran besar didalamnya. Berbagai kalangan akademisi, birokrat hingga praktisi bisnis telah mempercayai jika analisis dengan mempergunakan perspektif SWOT telah dianggap memiliki keunggulan. Kita bisa memberikan peta kondisi terhadap keadaan yang terjadi berdasarkan realita yang ada, serta lebih jauh mampu memberikan penegasan terhadap keputusan yang akan kita lakukan dimasa yang akan datang (Fahmi, 2013).

Oleh karena itu secara umum ada beberapa kegunaan dengan dipergunakannya analisa SWOT dalam mendukung manajemen pengambilan keputusan (Fahmi, 2013).

1. Mampu memberikan gambaran suatu organisasi dari empat sudut dimensi, yaitu strenght, weaknesses, opportunities, dan threats. Sehingga pengambil keputusan bisa melihat dari empat dimensi ini secara lebih komprehensip

2. Dapat dijadikan sebagai rujukan pembuatan rencana keputusan jangka panjang

3. Mampu memberikan pemahaman kepada para stakeholders yang berkeinginan menaruh simpati bahkan bergabung dengan perusahaan dalam suatu ikatan kerja sama yang saling menguntungkan

4. Dapat dijadikan sebagai penilai secara rutin dalam melihat progres report dari setiap keputusan yang telah dibuat selama ini.

\section{Tujuan Penerapan SWOT}

Penerapan SWOT pada suatu perusahaan bertujuan untuk memberikan suatu panduan agar perusahaan menjadi lebih fokus, sehingga dengan penempatan analisa SWOT tersebut nantinya dapat dijadikan sebagai bandingan pikir dari berbagai sudut pandang, baik dari segi kekuatan dan kelemahan serta peluang dan ancaman yang mungkin bisa terjadi dimasa-masa yang akan datang. Tujuan lain diperlukan analisa SWOT adalah dimana setiap produk yang beredar dipasaran pasti akan mengalami pasang surut dalam penjualan atau yang dikenal dengan istilah daur hidup produk. Konsep daur hidup produk dirujuk berdasarkan keadaan relita yang terjadi dipasar, bahwa konsumen memiliki tingkat kejenuhan dalam memakai suatu produk. Untuk lebih jelasnya kita dapat melihat gambar dibawah ini (Nitisemito, 1986).

\section{Matriks Evaluasi Faktor Internal}

Matriks evalusi faktor internal (Internal factor evaluation-IFE Matrix)adalah tahan ekstraksi dalam menjalankan audit manajemen strategi. Alat formulasi strategi ini meringkas dan mengevaluasi kekuatan dan kelemahan utama dalam era fungsional bisnis, dan juga memberikan dasar untuk mengidentifikasi dan mengevaluasi hubungan untuk mengembangkan Matriks IFE, jadi kemunculan pendekatan ilmiah tidak seharusnya diartikan bahwa faktor-faktor yang dimasukkan lebih dari pada angka yang sebenarnya. Matriks IFE dapat dikembangkan dalam lima tahap (David 2006).

1. Tuliskan faktor internal utama seperti identifikasi dalam proses audit. Gunakan faktor internal mencakup kekuatan dan kelemahan. Tuliskan kekuatan lebih dahulu dan kemudian kelemahan, buatlah sespesifikmungkin gunakan persentase, ratio, dan angka komparatif.

2. Berikan bobot berkisar 0,0 (tidak penting) hingga 1,0 (sangat penting) untuk masingmasing faktor. Bobot yang diberikan kepada masing-masing faktor mengindikasikan tingkat penting relative memandang apakah 
faktor kunci itu adalah kekuatan atau kelemahan internal, faktor yang dianggap memiliki pengaruh paling besar dalam kinerja organisasi harus diberikanbobot tinggi.jumlah seluruh bobot harus sama dengan 1,0.

3. Berikan peringkat 1 sampai 4 untuk masingmasing faktor untuk mengindikasikan apakah faktor tersebut menunjukan kelemahan utama (peringkat $=1$ ), atau kelemahan minor $($ peringkat $=2)$, kekuatan minor $($ peringkat $=$ 3 ), atau kekuatan utama (peringkat $=4$ ). Perhatikan kekuatan harus mendapat peringkat 3 atau 4 dan kelemahan harus mendapatkan nilai 1 atau 2. Peringkat berdasarkan perusahaan, dimana bobot di langkah 2 adalah berdasarkan industri.

4. Kalikan masing-masing bobot faktor dengan peringkat menentukan ratarata tertimbang untuk masing-masing variabel.

5. Jumlahkan rata-rata tertimbang untuk menentukan total rata-rata tertimbang untuk organisasi. Berapapun banyak faktor yang dimasukkan dalam matriks IFE, total ratarata tertimbang berkisar antara yang terendah 1,0 dan tertinggi 4,0 dengan ratarata 2,5. Total rata-rata tertimbang dibawah 2,5 menggambarkan organisasi yang lemah secara internal, sementara total nilai diatas 2,5 mengindikasikan posisi internal yang kuat. Jumlah faktor memiliki pengaruh terhadap kisaran total ratarata tertimbang karena bobot selalu berjumlah 1,0 .

\section{Matriks Evaluasi Faktor Eksternal}

Matriks evaluasi faktor eksternal yang memungkinkan para penyusunstrategi untuk merangkum dan mengevaluasi informasi ekonomi, sosial, budaya, demografi, lingkungan, politik, pemerintahan, hukum, teknologi dan persaingan. Matriks EFE dapat dibuat dengan lima tahap (David 2006).

1. Buat daftar faktor eksternal yang di identifikasi dalam proses auditeksternal. Tuliskan peluang terlebih dahulu kemudian ancaman. Usahakanspesifik menggunakan persentasi, rasio, dan nilai komparatif bila mungkin.

2. Berikan bobot masing-masing faktor dari 0,0 (tidak penting) hingga 1,0 (paling penting). Bobot mengindikasi tingkat penting relative dari faktor terhadap keberhasilan perusahaan dalam suatu industri. Peluang sering kali diberikan bobot lebih tinggi dari pada ancaman, tetapi ancaman juga dapat di berikan bobot di lebih tinggi jika mereka sangat serius atau sangat mengancam. Bobot yang tepat dapat ditentukan dengan membandingkan keberhasilan atau kegagalan persaingan atau dengan mendiskusikan faktor. Penjualan dari seluruh bobot yang diberikan semua faktor harus sama dengan 1,0 .

3. Berikan peringkat 1 hingga 4 untuk masingmasing faktor eksternal kunci

tentang seberapa efektif strategi perusahaan saat ini dalam memproses faktor tersebut, di mana $4=$ respon perusahaan superior, $3=$ respons perusahaan diatas rata-rata, $2=$ respons perusahaan rata-rata, $1=$ respon perusahaan jelek. Peringkat didasarkan pada perusahaan (Companybased), sedangkan bobot pada tahap 2 didasarkan pada industry (industrybased). Penting diperhatikan bahwa ancaman dan peluang dapat diberikan 1, 2 ,3 atau 4.

4. Kalikan masing-masing bobot faktor dengan peringkatnya untuk memperoleh nilai tertimbang.

5. Jumlah nilai tertimbang dari masing-masing variabel untuk menentukan total nilai tertimbang bagi organisasi.

6. Tanpa Mempedulikan jumlah peluang dan ancaman kunci yang dimasukkan dalam matriks EFE, total nilai tertimbang untuk suatu organisasi untuk suatu organisasi adalah 4,0 dan nilai tertimbang terendah adalah 1,0. Total nilai tertimbang rata-rata adalah 2,5. Total nilai tertimbang sebesar 4,0 mengindikasikan bahwa organisasi merespon dengan sangat baik terhadap peluang dan ancaman yang ada dalam industrinya. Dengan kata lain strategi perusahan secara efektif mengambil keuntungan dari peluang yang ada saat ini dan meminimalkan efek yang mungkin muncul dari ancaman eksternal. Total nilai1,0 mengindikasikanbahwa strategi perusahaan tidak dimanfaatkan peluang atau tidak menghindari ancaman eksternal.

Tabel 2. Diagram Matrik SWOT

\begin{tabular}{|c|c|c|}
\hline EFAS & $\begin{array}{l}\text { Kekuatan/Strengths (S) } \\
\text { Faktor-faktor kekuatan } \\
\text { Internal }\end{array}$ & $\begin{array}{l}\text { Kelemahan/ } \\
\text { Weaknesses (W) } \\
\text { Faktor-faktor kelemahan } \\
\text { Internal }\end{array}$ \\
\hline $\begin{array}{l}\text { Peluang/Opportunities } \\
\text { (0) } \\
\text { Faktor-faktor peluang } \\
\text { eksternal }\end{array}$ & 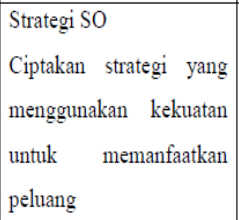 & $\begin{array}{l}\text { Strategi WO } \\
\text { Ciptakan stategi yang } \\
\text { meminimalkan } \\
\text { kelemahan untuk } \\
\text { memanfaatkan peluang }\end{array}$ \\
\hline $\begin{array}{l}\text { Faktor-faktor ancaman } \\
\text { eksternal }\end{array}$ & \begin{tabular}{|lr|}
\multicolumn{2}{|l|}{ Strategi ST } \\
Ciptakan & strategi yang \\
menggunakan & kekuatan \\
untuk & mengatasi \\
ancaman & \\
\end{tabular} & $\begin{array}{l}\text { Strategi WT } \\
\text { Ciptakan strategi yang } \\
\text { meminimalkan } \\
\text { kelemahan dan } \\
\text { menghindari ancaman }\end{array}$ \\
\hline
\end{tabular}




\section{Metode Penelitian}
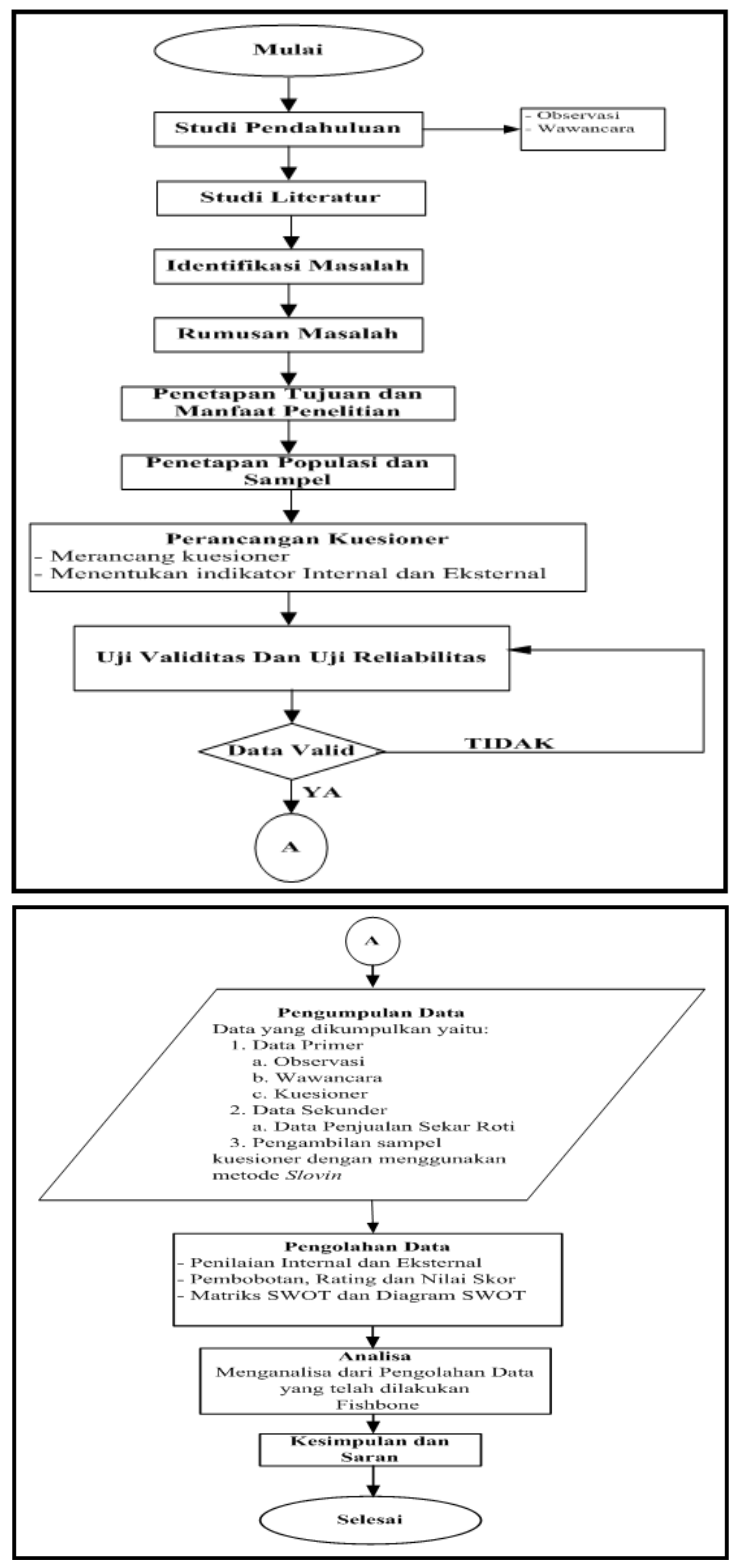

Gambar 3 Flow Chart Penelitian

Penelitian dilakukan dengan mengumpulkan data-data seperti, profil perusahaan, dan data - data penjuala yang ada di perusahaan. Agar dalam pelaksanaan penelitian dapat dijalankan dengan mudah serta sesuai dengan tujuan penelitian yang akan dicapai, maka diperlukan langkah pemecahan yang baik dan pada pemecahan masalah tersebut dibutuhkan data-data pendukung, adapun data-data yang diperlukan adalah :

\section{Data Sekunder}

Data Sekunder merupakan data yang tidak langsung dapat diamati oleh peneliti. Data ini merupakan dokumen perusahaan, adapun data sekunder dalam penelitian ini adalah data penjualan CV. Sekar Sari Roti dari tahun 2012 hingga tahun 2014.

\section{Hasil dan Pembahasan}

\section{Pengolahan Data}

\section{a. Pengumpulan Data}

Pengumpulan data dilakukan dengan menyebarkan kuesioner kepada pelanggan yang datang (Responden internal) dan kepada pihak perusahaan (Responden eksternal) CV. Sekar Sari Roti.

Tabel 3 Rekapitulasi Pengumpulan data kuesioner

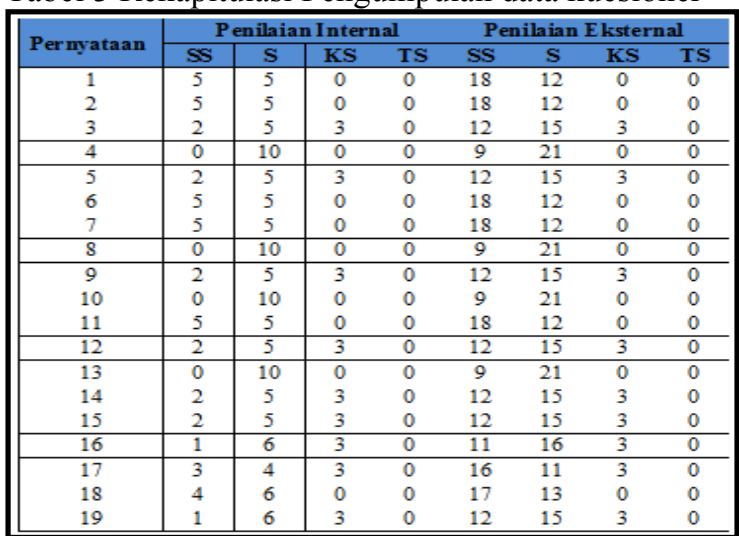

Setelah data kuesioner telah direkapitulasi, maka langkah selanjutnya adalah penilaian Internal Strategic Factors Analysis Summary (IFAS) dan Eksternal Strategic Factors Analysis Summary (EFAS) untuk setiap butir pertanyaan. Adapun perhitungan penilaian Internal dan Eksternal sebagai berikut:

$$
\text { Nilai }=\text { SS x 4+S x 3+KS x 2+TS x } 1
$$

\section{Keterangan}

$\begin{array}{ll}\text { SS } & : \text { Sangat Setuju } \\ \text { S } & : \text { Setuju } \\ \text { KS } & : \text { Kurang Setuju } \\ \text { TS } & : \text { Tidak Setuju }\end{array}$

1. Produk yang dimiliki Sekar Sari Roti beragam, dengan keberagaman produk Sekar Sari Roti membuat pelanggan lebih leluasa memilih produk sesuai yang diingkan pelanggan.

a. Internal

$$
\begin{aligned}
\text { Nilai } & =\mathrm{SS} \times 4+\mathrm{S} \times 3+\mathrm{KS} \times 2+\mathrm{TS} \times 1 \\
& =(5 \times 4)+(5 \times 3)+(0 \times 2)+(0 \times 1) \\
& =20+15+0+0 \\
& =35
\end{aligned}
$$

b. Eksternal

$$
\begin{aligned}
\text { Nilai } & =S S \times 4+S \times 3+K S \times 2+\text { TS } \times 1 \\
& =(18 \times 4)+(12 \times 3)+(0 \times 2)+(0 \times \\
& =72+36+0+0 \\
& =108
\end{aligned}
$$


Tabel 4 Rekapitulasi nilai internal dan eksternal

\begin{tabular}{|c|c|c|}
\hline Pernyataan & Nilai Internal & Nilai Eksternal \\
\hline 1 & 35 & 108 \\
\hline 2 & 35 & 108 \\
\hline 3 & 29 & 99 \\
4 & 40 & 99 \\
5 & 29 & 99 \\
\hline 6 & 35 & 108 \\
\hline 7 & 35 & 108 \\
\hline 8 & 40 & 99 \\
\hline 9 & 29 & 99 \\
10 & 40 & 99 \\
11 & 35 & 108 \\
\hline 12 & 29 & 99 \\
\hline 13 & 40 & 99 \\
14 & 29 & 99 \\
15 & 29 & 99 \\
\hline 16 & 28 & 95 \\
\hline 17 & 20 & 103 \\
18 & 34 & 107 \\
19 & 28 & 99 \\
\hline
\end{tabular}

\section{Pembobotan IFAS dan EFAS}

Perhitungan ini didapat dari total Internal Strategic Factors Analysis Summary (IFAS) dan Eksternal Strategic Factors Analysis Summary (EFAS) dibagi dengan total Internal Strategic Factors Analysis Summary (IFAS) dan Eksternal Strategic Factors Analysis Summary (EFAS) untuk tiap variabel item pernyataan. Adapun perhitungan rumus penentuan pembobotan IFAS dan EFAS sebagai berikut :

a.

$$
\begin{aligned}
& \frac{\text { Bobot }=}{\text { Jumlah I+E }(\text { S dan } W)} \\
& =\frac{143}{1373} \\
& =0,1041
\end{aligned}
$$

b.

$$
\begin{aligned}
& \text { Bobot } \\
& \text { Jumlah I } \\
& =\frac{143}{1180} \\
& =0,121
\end{aligned}
$$$$
\frac{\mathrm{I}+\mathrm{E}}{\text { Jumlah } \mathrm{I}+\mathrm{E}(\mathrm{O} \text { dan } \mathrm{T})}
$$

Tabel 5 Rekapitulasi Pembobotan kuesioner

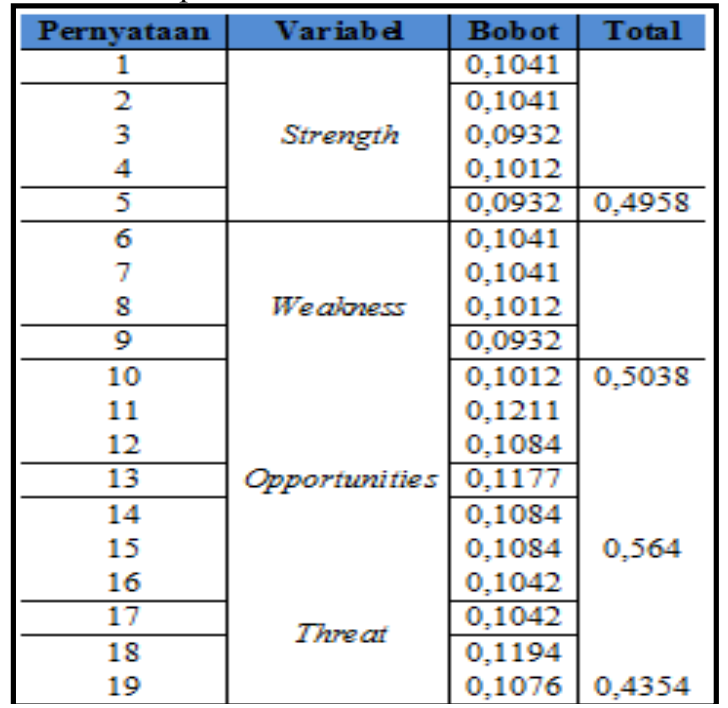

\section{Rating IFAS dan EFAS}

Penentuan rating pada Internal Strategic Factors Analysis Summary (IFAS) dan Eksternal Strategic Factors Analysis Summary (EFAS) berdasarkan penilaian responden atas kuesioner yang telah diberikan. Dalam penentuan rating diambil salah satu data sebagai contoh, sedangkan data yang lain direkap di dalamtabel. Adapun penentuan rating adalah sebagai beriku:

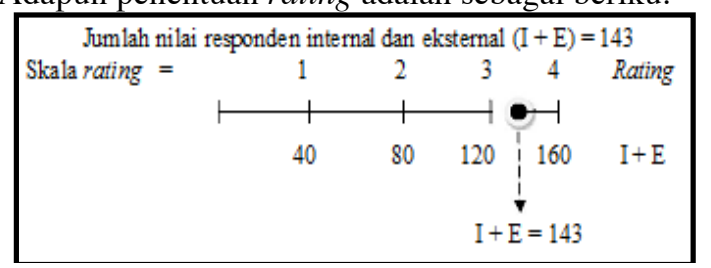

Tabel 1.6 Rekapitulasi Rating kuesioner 


\begin{tabular}{|c|c|c|}
\hline Pernyataan & $\overline{\text { Variabel }}$ & $\overline{\text { Rating }}$ \\
\hline 1 & \multirow{5}{*}{ Strength } & 4 \\
\hline 2 & & 4 \\
\hline 3 & & 4 \\
\hline 4 & & 4 \\
\hline 5 & & 4 \\
\hline 6 & \multirow{6}{*}{ Weakness } & 4 \\
\hline 7 & & 4 \\
\hline 8 & & 4 \\
\hline 9 & & 4 \\
\hline 10 & & 4 \\
\hline 11 & & 4 \\
\hline 12 & \multirow{8}{*}{ Opportunities } & 4 \\
\hline 13 & & 4 \\
\hline 14 & & 4 \\
\hline 15 & & 4 \\
\hline 16 & & 4 \\
\hline 17 & & 4 \\
\hline 18 & & 4 \\
\hline 19 & & 4 \\
\hline
\end{tabular}

Perhitungan Nilai Skor

Perhitungan ini didapat dari perkalian bobot Internal Strategic Factors Analysis Summary (IFAS) dan Eksternal Strategic Factors Analysis Summary (EFAS) didengan dengan rating Internal Strategic Factors Analysis Summary (IFAS) dan Eksternal Strategic Factors Analysis Summary (EFAS) untuk tiap variabel item pernyataan. Adapun perhitungan rumus Rating IFAS dan EFAS sebagai berikut :

Jumlah Bobot item kuisioner di kali jumlah Rating item kuisioner

$$
\begin{aligned}
& \text { Bobot }=0,1041 \\
& \text { Rating }=4 \\
& \text { Bobot x Rating }=\text { Nilai Skor } \\
& 0,1041 \times 4 \quad=0,4164
\end{aligned}
$$

Tabel 4.15 Rekapitulasi Total Nilai Skor

\begin{tabular}{|c|c|c|l|}
\hline \multicolumn{2}{|c|}{ Faktor } & Total Skor & Difference \\
\hline \multirow{2}{*}{ Internal } & Strength & 1,9832 & $=1,9832-2,0152$ \\
& Wealness & 2,0152 & $=-0,032$ \\
\hline \multirow{2}{*}{ Ekstemal } & Opportunity & 2,2562 & $=2,2562-1,7416$ \\
\cline { 2 - 3 } & Threat & 1,7416 & $=0,5144$ \\
\hline
\end{tabular}

Maka diketahui nilai Weakness lebih tinggi dibandingkan nilai Strength dengan selisih - 0,032 dan nilai Oppurtunity lebih tinggi dibandingkan nilai Threat dengan selisih 0,5144. Dari hasil identifikasi faktor-faktor tersebut maka dapat digambarkan dalam diagram SWOT sebagai beriku.

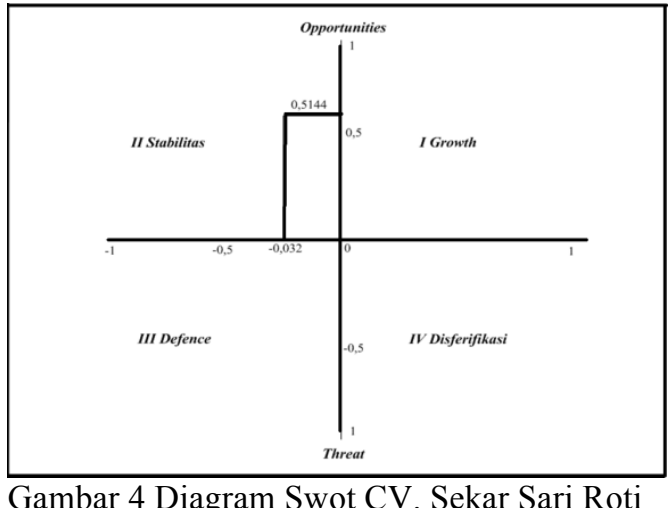

Gambar diatas menunjukkan bahwa CV. Sekar Sari Roti berada pada kuadran II atau Stabilitas yaitu perusahaan memanfaatkan peluang

\begin{tabular}{|c|c|c|}
\hline \multicolumn{3}{|c|}{ Tabe1 4.17 Matriks Perencanaan Kombinasi Strategi } \\
\hline $\begin{array}{ll}\text { IFAS } \\
\text { EFAS }\end{array}$ & Strength (S) & Weakness $(W)$ \\
\hline Opportunity (O) & $\begin{array}{l}\text { Strategi (SO): } \\
\text { Menggunakan kekuatan untuk } \\
\text { memanfaatkan peluang sebesar } \\
4,2394\end{array}$ & $\begin{array}{l}\text { Strategi (WO): } \\
\text { Meminimalkan kelemahan } \\
\text { untuk memanfaatkan peluang } \\
\text { sebesar } 4,2714\end{array}$ \\
\hline Threat $(T)$ & $\begin{array}{l}\text { Strategi (ST): } \\
\text { Menggunakan kekuatan untuk } \\
\text { mengatasi ancaman sebesar } \\
3,7248\end{array}$ & $\begin{array}{|lr|}\text { Strategi(WT): } & \\
\text { Meminimalkan } & \text { kelemahan } \\
\text { menghindari } & \text { ancaman } \\
\text { sebesar } \mathbf{3 , 7 5 6 8} & \\
\end{array}$ \\
\hline
\end{tabular}
yang ada dengan meminimalkan kelemahan yang ada.

\begin{tabular}{|c|c|c|}
\hline \multicolumn{2}{|c|}{ Tabel 4.16 Rumusan Kombinasi Strategi Matrik SWOT } \\
IFAS & Strength (S) & Wealmess (W) \\
\multirow{4}{*}{ Opportunities (O) } & Strategi (SO) & Strategi (WO) \\
\cline { 2 - 3 } & $1,9832+2,2562$ & $2,2562+2,0152$ \\
$=4,2934$ & $=4,2714$ \\
\hline \multirow{4}{*}{ Threat (T) } & Strategi (ST) & Strategi (WT) \\
& $1,9832+1,7416$ & $20152+1,7416$ \\
\cline { 2 - 3 } & $=3,7248$ & $=3,7568$ \\
\hline
\end{tabular}

Berdasarkan matriks SWOT diatas maka terdapat 4 langkah strategi pada SWOT yaitu :

a. Strategi SO (Strengths - Opportunities)

Strategi ini dibuat dengan memanfaatkan seluruh kekuatan untuk merebut dan memanfaatkan peluang sebesar-be sarnya. Strategi SO menggunakan kekuatan internal perusahaan untuk memanfaatkan peluang eksternal.

b. Strategi ST (Strengths - Threats)

Strategi ini menggunakan keluatan yang dimiliki perusahaan untuk mengatasi ancaman. Strategi ST menggunakan kekuatan internal perusahaan untuk menghindari atau mengurangi dampak ancaman eksternal.

c. Strategi WO (Wealness - Opportunities)

Strategi ini dibuat berdasarkan pemanfaatan peluang yang ada dengan cara meminimalkan kelemahan yang ada. Strategi Wo bertujuan untuk memperbaiki kelemahan internal dengan memanfaatkan peluang eksternal.

d. Strategi WT (Wealness - Threat)

Stratgei ini didasarkan pda kegiatan yang bersifat defensive dan berusaha meminimalkan kelemahan serta menghindari ancaman. Strategi WT bertujuan untuk mengurangi kelemahan internal dengan menghindari ancaman eksternal

\section{b. Diagram Fishbone}

Diagram fishbone digunakan untuk mengetahui penyebab terjadinya kelemahan perusahaan dan penyebab apa yang paling dominan 
menimbulkan kelemahan pada perusahaan. Adapun diagram fishbone kelemahan perusahaan adalah sebagai berikut :

\section{Kelemahan Perusahaan}

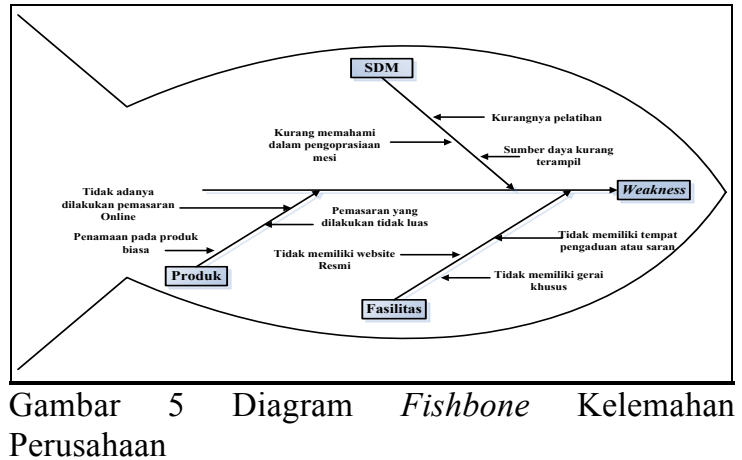

\section{Kesimpulan}

Berdasarkan tujuan penelitian yang telah disebutkan sebelumnya maka

peneliti dapat mengambil kesimpulan sebagai berikut :

1. Dari analisis bobot, rating dan nilai skor faktor Internal didapatkan total nilai skor 1,9832 untuk kekuatan perusahaan dan 2,0152 untuk kelemahan perusahaan yang berarti bahwa CV. Sekar Sari Roti memiliki posisi internal yang lemah dan nilai skor faktor eksternal dengan total nilai skor 2,256 untuk peluang perusahaan dan 1,7416 untuk ancaman pada perusahaan yang berarti bahwa CV. Sekar Sari Roti kurang memiliki posisi eksternal yang kuat.

2. Dari analisa diagram SWOT CV. Sekar Sari Roti berada pada posisi kuadran II atau Stabilitas yaitu WO, yang menunjukkan bahwa CV. Sekar Sari Roti memiliki internal yang lemah namun meiliki eksternal yang kuat dengan memanfaatkan peluang perusahaan yang besar untuk meminimalkan kelemahan perusahaan.

3. Analisa perencanaan kombinasi strategi menunjukkan bahwa CV. Sekar Sari Roti lebih fokus kepada strategi Weakness Opportunity (WO) karena memiliki nilai skor tertinggi dari nilai skor strategi lainnya yaitu sebesar 4,2714 yaitu berdasarkan pemanfaatan peluang yang ada dengan cara meminimalkan kelemahan yang ada.
Adapun saran yang dapat peneliti berikan adalah sebagai berikut:

1. Bagi peneliti

Diharapkan dari hasil penelitian ini dapat bermanfaat sebagai pengembangan dan pengetahuan, khususya dalam manajemen pemasaran.

2. Bagi perusahaan

Dengan adanya penelitian ini diharapkan CV. Sekar Sari Roti dapat mengaplikasikan hasil penelitian yang diperoleh untuk meningkatkan penjualan.

3. Bagi universitas

Dengan adanya penelitian ini diharapkan dapat menjadi sumber ide bagi penelitipeneliti yang ingin mendalami permasalahan ini selanjutnya, seperti bagaimana cara mengubah penampilan perusahaan lebih menarik atau pada kasuskasus lainnya.

\section{Daftar Pustaka}

Afrillita, Nur. Analisa SWOT dalam menentukan strategi pemasaran sepeda motor. Vol 10 No. 3 (2013).

AG, Hartono, Tri, Sigit. Analisa SWOT dan penetapan strategi pemasaran. Vol. 1 No. 1 April 2013

Dajan, Anto. Pengantar metode statistic jilid 1, Jakarta. 1986

Diniaty, Dewi, Agusrinal. Perancangan strategi pemasaran anyaman pandan. Vol. 11 No. 2, Juni 2014.

Erhard, Valentine K. Away with SWOT analysis use defensive/offensive evaluation instead. Vol. 21 No. 2, Maret 2005.

Freedy, Rangkuti. Riset Pemasaran, PT. Gramedia Pustaka Utama Jakarta. 1996

Freedy, Rangkuti. SWOT Balanced Score Card, Penerbit Gramedia Pustaka Utama, Jakarta. 2011

Gazpers, Vincent. Statistik dan Probabilitas, Penerbit Gramedia. 2003

Gay, L.R dan Diehl, P.L (1992), Research Methods for Business and Management, Macmillan Publishing Company, New York

Nugroho, Ryan. Pengaruh people, physical evidence, product, promotion, price and place terhadap tingkat kunjngan di café coffe cozies. Vol. 1 No 2 (2003).

Putra, Dedi. Position analysis and marketing strategy in using its competition analytical herarchy proses (AHP), competitive profile matrix ( CPM ) and internal external matrix (Matrix IE). Skripsi Universitas Islam Negri Sultan Syarif Kasim Riau. 

dalam Bidang Teknik Industri

Ridwan. Belajar mudah penelititan Untuk Guru, Karyawan dan Peneliti Pemula, Bandung. 2005
Rifqi, Farid. Analisis strategi Dea Cake and Bakery di kota Kepanjen. Vol 2 No 12 maret 2015. 